\title{
Expansion without equity: an analysis of current policy on access to higher education in Brazil*
}

Tristan McCowan, Institute of Education, University of London

\begin{abstract}
Access to higher education in Brazil is to a large extent restricted to the higher socioeconomic groups. Public universities have limited places and entry is determined by highly competitive exams, thereby excluding those who have not had a high quality secondary education or attended an expensive preparatory course. There has been considerable growth in the private sector to absorb the excess demand, but the majority of Brazilians cannot afford the fees. This paper develops a concept of equity in higher education in which, firstly, there should be sufficient places in the system as a whole and, secondly, all people should have a fair opportunity of attending the university of their choice regardless of socioeconomic background. Recent efforts to expand access are analyzed, including incentives for the growth of private universities, student loans and the new Prouni initiative, in which private institutions provide free places to low-income students in return for tax exemptions. While these initiatives have the potential to increase the total number of places, they will not lead to an equitable expansion, as disadvantaged students will still be confined to courses of lower quality or with lower subsequent value on the employment market. Initiatives aimed at the public sector such as the introduction of quotas and changes to entry examinations are also discussed. Finally, some implications for future policy development are outlined.
\end{abstract}

\section{Key words: access, Brazil, equity, expansion, higher education policy, private universities, public universities}

\section{Introduction}

In the past few decades there has been a dramatic increase in the number of students attending higher education institutions (HEIs) worldwide. Global enrolments rose from 13 million in 
1960 to 65 million in 1991, and are still rising rapidly in low, middle and high income countries alike (UNESCO 1995). While there has been some resistance to extending opportunities at the higher education (HE) level - on the basis of lack of funds or fears of a drop in standards - this has in most cases been overcome by the pressures of rising educational aspirations and the qualification requirements of the employment market (Husén 1976). Yet although expansion is undeniably a positive development, it has not in most cases brought about the hoped-for democratization, with inequalities little changed inside the institutions and outside in the wider society (Fulton 1992; Mora 1997; Robertson 1997; Dundar \& Lewis 1999).

Brazil is no exception to the worldwide phenomenon of rising HE enrolment. The total undergraduate $^{1}$ population rose from just over 1.5 million in 1992 to over 3.8 million in 2003 (INEP ${ }^{2}$ 2004). Yet access is still very restricted, with only $9 \%$ net enrolment, a figure that is all the more unacceptable given that Brazil is not a low income country, having a per capita GNP higher than that of the Russian Federation and over twice that of China (INEP 2003; World Bank 2003). The Brazilian government, currently engaged in a process of HE reform, is under considerable pressure to bring a further increase in enrolment ${ }^{3}$, and has adopted a number of policy strategies for this end.

This paper will analyse the current policies for expansion and increasing access, as well as some proposed future policies, to determine whether they represent a viable framework for equitable growth. The study is intended to contribute to the current debate on these issues within Brazil in the context of the long-awaited reform of the university system. Yet these concerns are not confined to Brazil, with similar policies being implemented in many other parts of the world (Dundar \& Lewis 1999; Ntshoe 2003; Siqueira 2004). The study, therefore, also aims to explore the wider implications of these policies, gauging them against a framework of educational justice.

This article also aims to engage with debates about the role of the private sector in HE. Private institutions are growing in number and size around the world and becoming more diverse, moving away from the traditional philanthropic and religious models (Altbach 1999; Geiger 1986; Maldonado-Maldonado 2004). Studies on Latin America (e.g. Levy 1986; Rhoades et al. 2004; Torres and Schugurensky 2002) have shown how in recent decades the countries have moved from small, elite public systems to diversified systems in which private institutions play a fundamental role. Some of these institutions cater to wealthy elites, but a growing number target lower-income students who are unable to enter the selective public universities. It remains to be seen whether the private sector represents a viable solution to the 
region's pressing need to expand the HE system, while at the same time maintaining teaching and research of a high quality.

Reform of higher education is unlikely to be successful in isolation from primary and secondary levels, and it is difficult for any university system to correct inequalities developed through the previous years of schooling. At the same time, higher education cannot absolve itself from all responsibility, placing the onus of its inequities on the previous levels. There are meaningful changes that can occur in the higher education system itself, and these will be the focus of this paper. Nevertheless, it is recognized that they will only be fully successful in context of reform of the whole educational system.

\section{Towards a conception of equity of access}

The term 'equity' has a long history and a wide variety of meanings. In the sense applicable here it is commonly associated with 'equality', although there are important differences between the two concepts (Le Grand 1991). The meaning of equity is close to that of fairness, and a fair distribution of a good is not necessarily an equal one. Equity is unlikely to mean equality of treatment, since, for example, it would clearly be unfair to make visually impaired students undergo the same entrance examination as those with sight. Neither is it likely to coincide with equality of outcome in all cases, since in most conceptions of fairness, there are justifiable reasons, such as effort and ability, that may lead to differing results. Equity is closest in meaning, therefore, to equality of opportunity and, like the latter, can be interpreted in a number of different ways.

The term equity has been widely adopted in recent years in relation to social and educational policy, particularly by development organizations such as the World Bank. The term's association with neo-liberal policies has led to some distrust among commentators, who see it as an abandonment of the goal of equality in favour of a false meritocracy that will favour the wealthy (Suárez 1995). These critiques, however, point to a diluted usage of the term, rather than inherent inadequacies of the concept as an element of educational justice.

In a previous study (McCowan 2004), two criteria were put forward as a basis for equitable access to HE. The first of these will here be modified slightly, with the introduction of a requirement for minimum preparation, given that no one can be expected to undertaken an HE course without some degree of academic experience and ability. The criteria are: 
1. There must be sufficient places so that all members of society who so desire, and who have a minimum level of preparation, can participate in higher education.

2. Individuals must have a fair opportunity of obtaining a place in the institution of their choice.

Many initiatives for expanding access to higher education are based solely on the first principle, aiming to increase the total number of places and therefore the proportion of the population enrolled. Yet while this is necessary and desirable, it is not sufficient, since certain individuals or groups may be systematically confined to lower quality institutions. An equitable system, therefore, will not only have sufficient places, but also an entry system that does not discriminate on unfair grounds.

This concept of equity, however, does not imply that universities can employ no selection criteria. In a system with sufficient places for all, some minimal selection is necessary to determine whether candidates are sufficiently prepared to undertake an HE course. On the other hand, in a situation where there are more people aiming to enter higher education than the number of places (true of most, if not all, countries today) greater selection will have to take place. Given the aims and requirements of the institutions as centres of learning and research, and the requirements of individuals to take full advantage of a university education, selection on the basis of academic potential in these circumstances is the least objectionable procedure. However, this selection should not be based on other factors such as socioeconomic background.

The Declaration of UNESCO's World Conference on Higher Education in 1998 states in relation to equity of access, that:

[A]dmission to higher education should be based on the merit, capacity, efforts, perseverance and devotion, shown by those seeking access to it, and can take place in a lifelong scheme, at any time, with due recognition of previously acquired skills. As a consequence, no discrimination can be accepted in granting access to higher education on grounds of race, gender, language or religion, or economic, cultural or social distinctions, or physical disabilities. (UNESCO 1998, Article 3)

This is a comprehensive statement of fair and unfair grounds for selection in higher education, and will provide the basis of the understanding of the second criterion used in this paper. The declaration also states that access for some specific groups, such as indigenous peoples and people with disabilities, must be actively facilitated. The reason 
given is that "these groups as collectivities and as individuals may have both experience and talent that can be of great value for the development of societies and nations". In addition, there may other justifications for policies of affirmative action, such as historical redress and current discrimination at previous stages in the education system.

It must be recognized that it can be very difficult to assess qualities like "merit, capacity, efforts, perseverance and devotion" in isolation of background factors of "race, gender, language or religion, or economic, cultural or social distinctions, or physical disabilities". Avoiding formal bans on, say, women or minority ethnic groups is not sufficient, as there are other ways in which these groups may be excluded. Meritocratic admissions procedures without formal discrimination have been the norm since the 1960s but many groups are still heavily underrepresented (Fulton 1992). Performance on entry examinations is of course dependent not only on ability and effort, but also on the quality of previous schooling, which is normally dependent on these background factors. So an equitable entry system would make some adjustments for these factors, in some cases leading to positive discrimination for certain groups. I would argue that this should go further than the Declaration's recommendation for positive discrimination in favour of specific targeted groups, and take into account previous schooling in relation to all prospective students. These efforts, however, must not undermine the academic integrity of the university, and minimum entry requirements should be maintained.

\section{Inequities in Brazilian higher education}

Equity is not a word commonly associated with Brazilian society. The country is one of the most unequal in terms of income distribution, and educational opportunities are distributed in a similarly unjust way. While some receive a first class university education, gross tertiary enrolment in 2002 was only 18\%, compared to 56\% in Argentina and 60\% in Poland, and the net rate, corresponding to the 18 to 25 age group, was as low as 9\% (UNESCO 2004, INEP 2003).

Brazilian HEIs are divided into three categories:

(1) Universities: institutions required to carry out research and community outreach (extensão) as well as teaching, to have at least $1 / 3$ of their teaching staff with Master's or $\mathrm{PhD}$ qualifications, and at least $1 / 3$ of their teaching staff working full time. They have the highest level of autonomy. 
(2) University centres: multi-course institutions not required to carry out research, but with autonomy to open new courses without the permission of the Ministry.

(3) Integrated faculties, faculties, and institutes or schools of HE: smaller institutions, with little autonomy, and which must have new courses approved one-by-one by the Ministry. (Neves, 2002)

Of the public institutions, those run by the federal and state levels are predominantly universities, while the municipal governments tend to run smaller technical institutes. There are private institutions of all three categories: of these, the 'university centres' usually provide lower-cost tuition, often of questionable quality.

An anomaly of the Brazilian system is that while prestigious institutions at the primary and secondary levels are in the private sector, the situation is reversed at HE level. Most of the best universities in the country are public, funded and controlled by the federal government or the individual state governments. However, standards in many of the public universities have dropped in recent years due to reductions in their budgets. These cuts were part of a wider reform programme undertaken in the Cardoso administration, which, following World Bank recommendations, reduced public spending and increased private involvement in all areas (Trindade 2003; Gentili 2001; Cunha 1999).

The private sector has always had a presence in Brazilian higher education, but has seen particular growth since the 1990s. An important distinction needs to be made between the traditional private universities and a new type that might best be called entrepreneurial. The former are mostly of religious affiliation, are non-profit and have an ethos similar to that of the public universities. The most prominent of these are the Catholic universities, known as $\mathrm{PUCs}^{4}$, found in the major cities. However, alongside these, a new group of profit-making (or highly commercialized non-profit) institutions has emerged, with a very different orientation from both public and traditional private institutions. They are primarily teaching institutions (even those of university status conduct little research) with an emphasis on rapid expansion and cost efficiency, employing aggressive marketing strategies in response to increasing competition. The larger institutions, such as the Universidade Paulista in São Paulo, often run on a franchise basis and operate visibility strategies, positioning campuses in prominent locations on high streets or even in shopping centres. These are the institutions in which the bulk of university expansion is occurring: five of the six largest institutions in the country are now private and over 78\% of new enrolments are in private institutions (INEP 2004). 
Access to Brazilian universities is regulated by the entrance examination known as the vestibular. This is normally unique to each institution, and selects candidates on the basis of academic performance. Since many courses are heavily oversubscribed, the exam is highly competitive, and many of the candidates consequently undertake preparatory courses, known as pré-vestibulares. The public universities are the most oversubscribed, with 8.4 candidates for every place, compared to 1.5 in the private sector, and there is considerable variation between courses, with even greater competition for prestigious disciplines such as medicine and law (INEP 2004).

This leads to the great irony of Brazilian higher education: given the highly competitive nature of the vestibular, it is very hard to enter a public university and receive a free higher education without having previously been to a private school and attended a private prevestibular course. This has led to many of the new private universities emphasizing their own social responsibility in catering for the lower socio-economic groups. However, while the introduction of some low-cost courses has enabled access for some lower-middle class students, fees for the majority of courses are out of the reach of most Brazilians, making the private sector as a whole as elitist as the public sector. According to research by the Brazilian Institute of Geography and Statistics (IBGE ${ }^{5}$ 2003), private universities have higher proportions of the richest $10 \%$ of the population $(50 \%$, compared with $34.4 \%$ in public institutions) and lower proportions of the poorest students (5\%, compared to $12 \%$ in public institutions).

For different reasons, therefore, access is limited to the higher socio-economic groups in both the public and private sectors. On top of this, there are racial inequities, with low representation of African Brazilians and indigenous peoples. Gender is a less serious concern in terms of initial access - females comprising 56\% of enrolments (INEP 2003) - although there are disparities in terms of the courses followed.

The injustice of the system is plainly apparent to the population of Brazil, its government and international agencies. The Cardoso government sought to resolve the problem through a rapid increase in the private sector, providing financial incentives for local ${ }^{6}$ entrepreneurs and easing quality restrictions. The current government of the Workers' Party (PT) under Lula da Silva has historically been opposed to privatization, and was expected to adopt a different policy framework. However there has so far been strong continuity with the policies of the Cardoso administration (Neves 2004). Lack of funds has meant that new enrolments in public universities actually dropped between 2002 and 2003 (despite the enormous demand for 
places), while there was an $8 \%$ increase in new enrolments in the private sector, with the latter's share now rising to $78 \%$ (INEP 2004). The goal of $40 \%$ of enrolments in public institutions by 2007 set by the National Education Plan now seems a distant dream (Brasil 2003).

The next section will discuss the initiatives currently in process, and assess their potential for contributing to equitable access. Some of these initiatives were initiated in the previous government, while others are new, forming part of the present government's high-profile university reform that is currently being finalized. Much of this proposed reform concerns the financing of the system as a whole and institutional autonomy from the State, but there are also important elements concerning equity of access.

In the following discussion, it must be acknowledged that issues of equity in HE go beyond initial access, and that it is not enough simply to ensure that people enrol, with no concern for their subsequent fate. It can be argued that the quota system and similar initiatives will not work because the students will be unable to survive financially for the duration of the course. While these are important questions, the current paper will only be able to address policies directed at initial access to undergraduate courses.

\section{Current initiatives for achieving equitable access}

The private sector

\section{Expansion of the private sector}

As stated above, the major pillar of higher education policy in Brazil in recent years has been the expansion of the private sector. The public sector has been viewed as costly and inefficient, and unable to provide the diversity of provision and the responsiveness to consumers necessary in the contemporary context. This policy has been successful in terms of increasing enrolment, total places having more than doubled since 1995 (INEP 2004).

Nevertheless, this expansion has certainly not been an equitable one. The main limitation is that the private sector allows access primarily to the wealthy and confines students from a lower socio-economic background to institutions and courses of lower quality. Course fees vary from approximately $\mathrm{R} \$ 150$ ( US\$50) a month to over $\mathrm{R} \$ 2000$, and there is a strong 
relation between the cost of the course and its quality, or alternatively, between the cost of obtaining the diploma and its subsequent value in the employment market (McCowan 2004).

This form of crystallization of initial inequalities can be softened by price controls, but they have been resisted on account of the negative effect on profit incentives for the institutions in question. Given that there are a very restricted number of places in the free public universities, young Brazilians - seeing a university diploma as the only means of attaining worthwhile employment - make great sacrifices to pay the costs of a private university education, leading to high profits and capital growth for the companies in question. Understandably, this increasingly powerful sector has resisted attempts to restrict its activities, and a number of associations have been formed to promote its interests, with strong lobbying power in the National Education Council ${ }^{7}$. It is consequently difficult to regulate the sector in favour of equity and quality.

Private sector expansion, therefore, has been very welcome to those seeking to demonstrate an increase in higher education enrolment, but has brought about a highly inequitable expansion ${ }^{8}$.

\section{Student loans and scholarships}

There have, however, been some attempts to allow students without the means of paying the full fees to attend private institutions. Most important of these is the student loans scheme, known as FIES ${ }^{9}$, which was initiated in 1999, replacing a previous scheme known as Creduc. The FIES provides a loan of $70 \%$ of the fees and is paid directly to the institution rather than the student. The interest charged is low by Brazilian standards and repayment begins in the first year after graduation $\left(\mathrm{MEC}^{10} 2004\right)$.

There is no doubt that the loan scheme has made some contribution to equity in Brazilian higher education. A total of 277,000 students have benefited from it since the programme was started, many of whom would not otherwise have been able to undertake a university course (Folha de São Paulo 2004b). However, there are a number of problems with this approach to solving the problem of equity in the long-term, firstly because of the malfunctioning of the system in the Brazilian context, and secondly because of the inherent limitations of a loan system. 
Initially, the scheme was only available to students if the loan was backed up by a guarantor with an income twice that of the total fees. This requirement, presumably implemented to avoid the high rates of non-payment of the previous scheme, meant that only those with some measure of financial security could obtain a loan, and was not, therefore, opening the door to higher education to those from the lowest socio-economic brackets. The system has been reformed in 2004, removing the requirement of a guarantor, and introducing weighting in the allocation of loans in favour of minority ethnic groups. There have also been efforts to increase the number of loans available, with the scheme doubling in size during the Ministry of Cristovam Buarque, and with another increase in 2004 from 35,000 to 50,000 loans per semester. However, it is still far from satisfying demand, with five candidates for every loan in 2004 (MEC 2004; Folha de São Paulo 2004b; 2004c).

Maintenance of the scheme is not easy on account of its high costs: only $35 \%$ of the money available to students comes from repayment of existing loans (the rates of non-payment are still high, currently at 22\%), with the rest coming from government funds. In 2004, R $\$ 872$ million was put aside in the budget for this end, making it a heavy burden on the public purse (Folha de São Paulo 2004a).

Even if reforms do bring an improvement in the functioning of the system, there are still arguments against it as a strategy for improving equity. Students from poor families may be unwilling to take on such large debt even at low rates of interest. Secondly, even if a loan can be obtained, the less affluent students are likely to remain in the lower cost courses, since the $30 \%$ remaining to be paid by the student for the expensive prestigious institutions can still be a heavy burden.

In addition to loans, there are some scholarships available from the private institutions themselves, covering part of the fees. Non-profit institutions are currently required by law to allocate $20 \%$ of their revenue towards funding free places in this way. However, this requirement is routinely abused with many institutions either failing to reach the $20 \%$ mark, or allocating the places not to needy students, but to relatives of their own staff (Davies 2002). Even if the system were functioning effectively, it would still provide only a limited proportion of the places, and certainly not enough to provide for all of those unable to afford the fees. Private institutions, many of which are profit-making, and all of which are under considerable financial pressure to increase revenues and reduce expenditure, are unlikely to increase the proportion of scholarships of their own accord. For these reasons, neither loans nor scholarships are the basis of a long-term policy strategy for equity. 
PROUNI: University For All

The Programa Universidade para Todos (University for All Programme), or Prouni as it has become known, is a new initiative of the Lula government, implemented in September 2004. Despite the high demand for HE in Brazil, there is considerable spare capacity in the system, as many places in private universities go unfilled due to inability of students to pay the fees. The HE census of 2002 determined that $37.5 \%$ of places in private institutions go unfilled in this way (INEP 2003). The idea of Prouni is to encourage these universities to allocate their unfilled places free of charge to low-income students, in return for exemption from tax payments. Non-profit institutions have to dedicate $20 \%$ of their places in this way in order to maintain their existing status of exemption from taxes. Profit-making institutions have the option to allocate $10 \%$ of their places in order to obtain exemption from some taxes. The places go to students from families whose per capita income is not more than 1.5 times the minimum wage. A total of 107,136 new places have been awarded in its year of inception (Brasil 2004a; Silveira 2005).

The Minister of Education, Tarso Genro, has called this initiative a 'nationalization' of private university places. Yet there has been strong opposition to the plan from university professors, rectors and students, and their respective unions, ANDES, ANDIFES and UNE, who believe that the money spent (or rather the money not collected) would be better used in the public universities. Perhaps surprisingly, there has also been some opposition from the private universities themselves. They pay very low taxes anyway (it is estimated that less than $2 \%$ of the total receipts of the private HE sector is paid in tax) and see the programme as a threat to their profitability. They are campaigning for changes in the requirements so as to reduce the proportion of free places they are obliged to provide in exchange for exemptions (Flor 2004a).

In terms of the efficiency of the system as a whole it is certainly a good thing that idle university places are filled. It is also good that the non-profit institutions, who are already enjoying significant exemption from taxes, are required to provide free places, and that their philanthropic activities and tax exemption are subject to greater regulation. The initiative will not bring high costs for the State as the private universities pay little tax anyway. It will also have the very positive result of bringing a rapid increase in enrolment in a short period of time. However, as with the previously mentioned initiatives, it is not a satisfactory long-term strategy for equity of access. The result of this policy will be to maintain the staggering growth of the private sector over that of the public sector. Institutions will have a lower risk 
of wastage through unfilled places, and therefore more incentive for expansion. The new free places will not 'democratize' the system, since the vast majority of places will still only be available to a small proportion of the population.

There are also concerns about the extent to which the requirements of providing free places will actually be fulfilled by the universities. As stated previously, the government has shown itself to be largely unable to control the activities of the private sector, due to the latter's financial power and the strong presence of its representatives in the state regulating body, the National Education Council (Neves 2002). Legal loopholes may make it possible for institutions to allocate fewer than the required places, or to allocate those places to students who are not from the specified target groups. Neither is there any guarantee that the extra places will be evenly distributed among the courses on offer: the majority of free places are likely to be given in subjects with a low demand or low cost. This means that in practice it is likely that many universities would enjoy greater tax exemption without making a significant contribution to the public good. While Prouni is a good short-term strategy for making use of spare capacity in the private sector, it is not the basis for equitable expansion of the system.

It has been seen, therefore, that expansion of the private sector on its own will not bring about equity of access. Initiatives such as the student loan scheme and Prouni are unlikely to function effectively in Brazil, and even if they did, providing funding for all, they would still not ensure equitable access. Not all policy developments, however, have been directed at the private sector: there have also been attempts to address the inequities of the public sector.

\section{The public sector}

\section{Quotas}

An important recent development in Brazilian HE is the implementation of quotas for particular groups, most importantly African Brazilians. This was not initially a national policy, but one implemented by individual universities in response to the demands of civil society groups, thereby causing a national debate and finally bringing the issue to the attention of the federal government.

Descendants of Africans make up a significant proportion of the Brazilian population (46.5\%, according to the National Census of 2000). Yet they have very low representation in HE, where they comprise under $20 \%$ of the total student population (IBGE 2000). The State 
University of Rio de Janeiro was the first to adopt the policy, implementing a quota of $40 \%$ of the total enrolment for African Brazilians, and a further 10\% for other students from public schools. Quotas were subsequently introduced in other important institutions such as the University of Brasília, and the Federal Universities of Bahia and Paraná.

The government has been forced to adopt a consistent position on this issue at a national level, and a new law has been proposed that would oblige all federal universities ${ }^{11}$ to set aside half of all their places to students from public schools, some of which would be reserved for African Brazilians and indigenous peoples depending on the proportions of these groups in the state in which the university is located (Brasil 2004b).

The issue of quotas has divided the HE community, with fierce opposition from individuals and institutions on both sides of the political spectrum. Polls have shown that a large majority of university rectors are against quotas (Flor 2004b). Those in favour, however, say that it is essential to rectify the historic and continuing exclusion of the black community, and that any more gradual approach to the problem would have an unacceptably long time-frame. There is a consensus among those in favour of quotas that they are a provisional, even emergency, measure and not a permanent solution, which would require wide-ranging social changes.

Quotas present a challenge to procedural justice, discriminating in favour of certain candidates on the basis of their background, so can only be justified in extreme circumstances. However, in Brazil there are grounds for such measures, given the deep and long-lasting exclusion of certain segments of society. Whether these quotas should include a racial element, rather than focusing solely on socio-economic factors (a major source of the dispute in Brazil) is an issue that exceeds the limits of this paper. Yet it does appear that quotas of some variety can make a positive contribution to equity, as a provisional measure while other longer term policies are taking their effect, and as long as some places are still available for all.

\section{ENEM}

Another proposal concerns the entry requirements for universities. In the proposed university reform, the vestibular exam is to be replaced by selection via results in the National Examination of Secondary Education (ENEM ${ }^{12}$ ), an existing assessment that would now be compulsory for school leavers nationwide. The ENEM is already used by almost a quarter of HEIs, but in the proposed reforms it would be used in all institutions, whether public or private, as at least part of the entry criteria (Globo 2004). 
The purpose of the change is to place the emphasis on high performance in secondary school, rather than a one-off, content-based and highly stressful competition for each HEI.

The proposed change has the advantage of removing the need for pre-vestibular courses, which are normally very expensive, and therefore not available to most of the population. Similar cramming courses might conceivably emerge for the ENEM, but would be unlikely to provide such a significant distortion. The removal of the vestibular would certainly not resolve all the inequitable elements of the entry system, but it would go a small way towards giving those without the money to attend private school a fair chance of entering university.

The contribution to equity of both this initiative and that of quotas is to the second of the criteria established above, namely that of ensuring that students have a fair opportunity of obtaining a place in the university of their choice. Neither contributes to the first criterion, that of ensuring sufficient places in the system as a whole. They are useful, therefore, only in conjunction with a policy of expansion.

\section{Initiatives for expanding enrolment in public universities}

As part of the current university reform, a number of proposals have emerged for expanding enrolments in the public sector without increasing expenditure. Firstly, there have been suggestions that university lecturers should increase their hours of contact time, and that class sizes should expand, meaning that public universities can admit a larger number of students with no additional funds. It is certainly right that the government should look to implement reforms to increase the efficiency of the public system, so that money is not wasted and human resources are used effectively. However, the strategies proposed here would have an inevitable, and probably unacceptable, effect on the quality of tuition. Any significant increase in lecturers' teaching workloads would mean that they were effectively being removed from their function as researchers, and that their students would consequently suffer from the loss of contact with new developments in the field. While not always the case, it is likely that an increase in class size would also have a negative effect on quality of teaching. This is not to say that there are no inefficiencies in the public system, nor that the teaching staff cannot be used more effectively. Yet the sector has already suffered serious cutbacks there has been negligible increase in staffing in federal universities since 1994, despite considerable growth in student numbers, with new positions filled by part-time staff on 
temporary contracts - and further stretching of resources would have serious consequences for quality (Siqueira 2004).

The second main proposal is that of distance education. A new institution, the Darcy Ribeiro Distance Education Institute, is to be created to help achieve the goal of having 500,000 students in distance education by the year 2007. This strategy has the advantage of bringing a rapid increase in enrolment at low cost. It may also have the advantage of allowing access for students in remote areas of the country who are not in reach of conventional universities. If there are students who would prefer to conduct their studies in the distance mode, then it would indeed be a welcome development. However, it would not constitute an equitable policy if some students were confined to distance education - the quality of which is in many cases a cause for concern - with no option for conventional contact study. According to Siqueira (2004), the proposals would mean that only 100,000 of 600,000 projected new places in federal universities would be in conventional mode, with the rest in distance education.

\section{Conclusion}

Studies show a progressive blurring of the boundaries between public and private in HE (Geiger 1986; Levy 1986), and this is evident in the case of Brazil. Yet there is a significant distinction between free-of-charge public institutions and fee-charging private institutions (particularly those of the entrepreneurial type) in terms of equity, quality and contribution to the public good. The above analysis of different policy initiatives for expanding the HE system in Brazil leads to the conclusion that an equitable expansion is possible only through investment in the public sector. The private sector has succeeded in bringing, and can continue to bring, a rapid increase in enrolments, and so contributes to equity according to the first criterion established above. However, this is not an equitable expansion, since students of lower socio-economic background are for the most part confined to courses of lower quality or lower subsequent value. Government interventions such as student loans and the proposed Prouni can increase access for lower-income students, but they do so in a limited way and cannot be the basis of successful long-term policy. Current proposals for expanding access to public institutions - through increase in staff workload, class size and distance education - are not sufficient, as they are likely to constitute a reduction in the quality of instruction. Measures to increase efficiency must be accompanied by an increase in total funds to counterbalance the neglect of the system in the past decade and allow for an expansion with quality. 
There are two main objections to claims that HE expansion should be carried out through free-of-charge public universities. The first is that a public system is not necessarily equitable, and that access is still difficult for some social groups even when there are no fees. The second is that governments are unable to bring an expansion in the HE system using public funds alone, especially in low and middle-income countries.

The first objection is clearly relevant to the case of Brazil, where those who have not attended private schools are unlikely to pass the highly competitive exams allowing entry to the prestigious public institutions. Even in a less dramatically unequal (although still, of course, unequal) country like the UK, the absence of fees until 1998 did not ensure satisfactory representation of working class students. This is not, however, an argument against the expansion of the public sector. It is a reflection of the distribution of opportunities in the education system at primary and secondary levels, as well as the methods of selection employed by universities. An expansion of the public HE system in Brazil must be accompanied by reforms in the education system as a whole, ensuring a high quality of schooling for all the population. Until this has happened, HE institutions should adopt some measures for compensating for the inequities earlier in the system, enabling students with a high academic potential but unsatisfactory previous schooling to enter university. Initiatives such as quotas and the adoption of the ENEM and other new methods of selection may go some way towards achieving this. Other strategies such as active recruitment among marginalized populations and the provision of more evening courses should also be considered.

A common objection is that of the inability of States to fund higher education - a widely accepted belief that lies behind current movements towards privatization across the world. It is indeed unrealistic to expect vastly increased budgets for higher education, given the competing demands from other levels of the educational system, not to mention other services such as health and housing. However, that does not mean that no additional money can be found or that existing funds cannot be better spent. In 2004, R\$ 829 million of public money in Brazil was transferred to the private universities through the student loan scheme, much of which will not be repaid (Salomon \& Constantino 2004). Considerable amounts of State funding are also transferred to the private institutions through tax exemptions, cheap loans and grants (Davies 2002). Non-profit private institutions receive over $\mathrm{R} \$ 800$ million a year in tax exemptions, the amount needed to create 520,000 new places in the federal universities, according to a study by the former education minister Cristovam Buarque (Salomon \& Constantino 2004). Meanwhile, the annual budget for federal universities dropped by $24 \%$ between 1995 and 2002, with a 70\% drop in investment in infrastructure in the same period. It 
is not that the State is unable to fund an expansion in public sector, but that successive governments have made a conscious decision to channel investment into the private sector a phenomenon that has been seen across Latin America (Rhoades et al. 2004).

Providing free higher education to a large proportion of the population is not, of course, an easy task. Universities of a high quality are extremely expensive to run, and countries like Brazil with limited government budgets must work hard to maintain them. Efforts must be made to avoid a loss of quality as a result of the expansion, as has occurred in other countries such as Turkey (Dundar and Lewis 1999). Yet if an equitable expansion is to be achieved, this is the only option available. The present government has announced a small expansion of the public sector as part of the new HE reforms, with two new federal universities and two new campuses of existing universities to be established. Yet the expansion must be more consistent and involve a reversal of the reduction in university budgets for existing institutions as well as the establishment of new institutions. Proposals for alternative methods of raising funds for public $\mathrm{HE}$ and better allocation of existing resources should be considered, as long as they do not compromise the fundamental requirements of equity and quality.

It may be that in practice expansion through the public sector in Brazil is slower than through the private sector. This is lamentable but still preferable to an expansion that will crystallize inequalities in society and not allow a fair opportunity for all to participate in higher education.

* An earlier version of this paper was presented at the World Congress of Comparative Education Societies, Havana, $25^{\text {th }}-29^{\text {th }}$ October 2004.

\section{Notes}


${ }^{1}$ This paper will focus on entry to undergraduate courses, rather than graduate or other levels of study.

${ }^{2}$ Instituto Nacional de Estudos e Pesquisas Educacionais.

${ }^{3}$ The number of students completing secondary education in Brazil has risen from 540,000 in 1980 to 1.9 million in 2002 (INEP 2002).

${ }^{4}$ Pontifícia Universidade Católica.

${ }^{5}$ Instituto Brasileiro de Geografia e Estatísticas.

${ }^{6}$ There has not as yet been significant investment in Brazilian HE by foreign companies: however, the recent partnership between the Apollo Group and Pitágoras in developing a new chain of HEIs may signal the start of new interest from abroad (McCowan 2004).

${ }^{7}$ This is the national agency responsible for, among other things, accreditation and regulation of HEIs.

${ }^{8}$ A more detailed account of the implications of private sector expansion can be found in McCowan (2004).

${ }^{9}$ Programa de Financiamento Estudantil.

${ }^{10}$ Ministério da Educação.

${ }^{11}$ Proposals to implement a similar law for private universities have not been followed through.

${ }^{12}$ Exame Nacional do Ensino Médio.

\section{References}

Altbach, P. (Ed) (1999) Private Prometheus: private higher education and development in the 21st century. Westport, CT: Greenwood Press.

Brasil, Federal Government (2003) Bases for addressing the emergency crisis of the federal universities and schedule for the Brazilian university reform. Report of the Inter-ministerial Work Group, Brasília, DF.

Brasil, Federal Government (2004a) Projeto de Lei 3582/2004. Subchefia de Assuntos Parlementares, 28 April.

Brasil, Federal Government (2004b) Projeto de Lei - Sistema Especial de Reserva de Vagas. Subchefia de Assuntos Parlementares, 28 April.

Cunha, L. A. (1999) O público e o privado na educação superior brasileira: fronteira em movimento? In H. Trindade (Ed.) Universidade em Ruinas: na Repíblica dos Professores. Petrópolis: Vozes.

Davies, N. (2002) Mecanismos de financiamento: a privatização dos recursos públicos, in L. M. W. Neves (ed.) O Empresariamento da Educação (São Paulo: Xamã).

Dundar, H. and Lewis, D. R. (1999) Equity, quality and efficiency effects of reform in Turkish higher education. Higher Education Policy. 12, 343-366. 
Flor, A. (2004a) Particulares tentam mudar Universidade para Todos. Folha de São Paulo, 27 May.

Flor, A. (2004b) MEC estuda loteria para financiar federais. Folha de São Paulo, 8 July.

Folha de São Paulo (2004a). Negro terá prioridade em financiamento. Folha de São Paulo, 18 July 2004.

Folha de São Paulo (2004b). Ministério Público consegue liminar para retirar fiador do Fies. Folha de São Paulo, 3 August 2004.

Folha de São Paulo (2004c) Inscrições no Fies superam em 5 vezes benefícios disponíveis. Folha de São Paulo, 20 September 2004.

Fulton, O. (1992) Equality and Higher Education. In B. R. Clark, \& G. Neave (Eds) The encyclopaedia of higher education: volume 2 analytical perspectives. Oxford: Pergamon Press.

Geiger, R. (1986) Private sectors in higher education: structure, function and change in eight countries. Ann Arbour: University of Michigan.

Gentili, P. (2001) A universidade na penumbra: o círculo vicioso da precariedade e a privatização do espaço público. In P. Gentili (Ed) Universidades na Penumbra. São Paulo: Cortez.

Globo (2004) Reforma universitária do governo prevê fim do vestibular. O Globo, 8 March 2004.

Husén, T. (1976) Problems of securing equal access to higher education: the dilemma between equality and excellence. Higher Education, 5, 407-422.

IBGE (2000) Censo Demográfico 2000: Educação, Resultados da Amostra. Rio de Janeiro: IBGE.

IBGE (2003) Pesquisa nacional por amostra de domicílios 2001. Rio de Janeiro: IBGE.

INEP (2003) Censo da educação superior 2002. Brasília: INEP.

INEP (2004) Censo da educação superior 2003. Brasília: INEP.

Le Grand, J. (1991) Equity and Choice. London: Harper Collins. 
Levy, D. (1986) Higher Education and the State in Latin America: private challenges to public dominance. Chicago: University of Chicago Press.

Maldonado-Maldonado, A. (2004) Private Higher Education: Trends in Research. In A. MaldonadoMaldonado, Y. Cao, P. G. Altbach, D. C. Levy and H. Zhu, Private Higher Education: An International Bibliography. Chestnut Hill, Massachusetts /Albany, New York: Center of International Higher Education and Program for Research On Private Higher Education; pp 1-24.

McCowan, T. (2004) The growth of private higher education in Brazil: implications for equity and quality. Journal of Education Policy, 19(4), 453-472.

MEC (2004) Financiamento estudantil.. Available online at http://www.mec.gov.br/Sesu/fies/, accessed on 14 December 2004.

Mora, J.-G. (1997) Equity in Spanish higher education. Higher Education, 33, 233-249.

Neves, L. M. W. (ed.) (2002) O Empresariamento da Educação (São Paulo: Xamã).

Neves, L. M. W. (ed.) (2004) Reforma Universitária do Governo Lula: Reflexões para o Debate. São Paulo: Xamã.

Ntshoe, I. M. (2008) The political economy of access and equitable allocation of resources to higher education. International Journal of Educational Development, 23, 381-398.

Rhoades, G., Maldonado-Maldonado, A., Ordorika, I. and Velazquez, M. (2004) Imagining Alternativas to Global, Corporate, New Economy Academic Capitalism. Policy Futures in Education, 2 (2), 316-329.

Robertson, D. (1997) Growth without equity? Reflections on the consequences for social cohesion of faltering progress on access to higher education. Journal of Access Studies, 12, 9-31.

Salomon, M. and Constantino, L. (2004) Filantrópica ganha R\$ 839,7 mil de incentivo, Folha de São Paulo, 12 April.

Siqueira, A. C. de (2004) As más lições da experiência: as reformas da educação superior no Chile e na China e suas semelhanças com o caso brasileiro, in Neves, L. M. W. (ed.) (2004) Reforma Universitária do Governo Lula: Reflexões para o Debate. São Paulo: Xamã. 
Silveira, R-A (2005) Enem deixará de ser exigência para o Prouni, Folha de São Paulo, 25 January.

Suárez, D. (1995) O Princípio Educativo da Nova Direita, in P. Gentili (Ed.) Pedagogia da Exclusão: Crítica ao Neoliberalismo em Educação. Petrópolis: Vozes.

Torres, C. A. and Schugurensky, D. (2002) The political economy of higher education in the era of neoliberal globalization: Latin America in comparative perspective, Higher Education, 43(4), 429445.

Trindade, H. (2003) O discurso da crise e a reforma universitária necessária da universidade brasileira. In M. Mollis (Ed) Las Universidades en América Latina: ¿Reformadas o Alteradas? Buenos Aires: CLACSO.

UNESCO (1995) Policy Paper for Change and Development in Higher Education. Paris: UNESCO.

UNESCO (1998) World Declaration on Higher Education for the Twenty-First Century: Vision and Action, adopted at the World Conference on Higher Education, Paris, October 1998.

UNESCO (2004) Statistical Tables: Education. Available online at http://www.uis.unesco.org/TEMPLATE/html/Exceltables/education/ger_tertiary.xls ， accessed 14 December 2004.

World Bank (2003) GNI per capita 2003, Atlas method and PPP. Available online at http://www.worldbank.org/data/databytopic/GNIPC.pdf, accessed on 14 December 2004. 